\title{
Uniconazole Application to Container Medium Surface Prior to Planting Bedding Plants
}

\author{
J.E. Barrett, R.K. Schoellhorn, C.A. Bartuska, D.G. Clark, and \\ T.A. Nell \\ Environmental Horticulture Department, University of Florida, Gainesville, \\ FL 32611
}

Additional index words. Petunia $\times$ hybrida, Solenostemon scutellarioides, Impatiens wallerana, Catharanthus roseus, media spray, growth regulator

\begin{abstract}
Uniconazole was applied as a spray to the surface of container media prior to planting bedding plant plugs. This medium spray was compared to a standard wholeplant spray applied 2 weeks after planting. For petunia (Petunia $\times$ hybrida Vilm.) and coleus (Solenostemon scutellarioides L.) the efficacy of the medium spray was similar to the whole-plant spray. However, for impatiens (Impatiens wallerana Hook. f.) and vinca [Catharanthus roseus (L.) G. Don.] the medium spray had greater efficacy than the wholeplant spray. Increased concentrations of uniconazole in the medium spray decreased plant height; however, the effect of higher concentrations was greater in a medium without pine bark compared to a medium with pine bark as a component. In the above experiments, uniconazole was applied in a volume of $200 \mathrm{~mL} \cdot \mathrm{m}^{-2}$. In a test where spray volume varied, there was a negative linear relationship between plant height and spray volume. Chemical name used: (E)-(+)-(S)-1-(4-chlorophenyl)-4,4-dimethyl-2-(1,2,4-triazol-1-yl)-pent-1-ane3-ol (uniconazole).
\end{abstract}

Uniconazole is the most active of the growth regulators used for height control of floriculture crops and is applied as a whole-plant spray or as a medium drench (Barrett, 2001; Barrett and Nell, 1992; Davis et al., 1988). In research trials, uniconazole or other medium-active growth regulators have been delivered by numerous other techniques, including impregnation in solid spikes (Barrett and Nell, 1994), in tablets (Sanderson et al., 1988), impregnation of clay pots (Einert, 1976), coating container surface (Barrett, 2000), soaking seeds prior to sowing (Pasian and Bennett, 2001), soaking corms or bulbs (Wulster and Ombrello, 2000), and through subirrigation water (Million et al. 1999a)

The objective of this research was to evaluate the potential of applying uniconazole as a spray to the medium surface prior to planting bedding plant plugs (seedlings). In most commercial situations, applying growth regulators as a whole-plant spray is easier and faster than applying a drench to the medium. However, uniconazole and other triazol growth regulators are very active through the medium and medium applications have fewer negative effects on flowering compared to whole-plant sprays. Therefore, a medium spray technique might combine the ease of using spray equipment with the benefits of medium applications.

Received for publication 26 Mar. 2001. Accepted for publication 31 July 2001. This research was supported by the Florida Agricultural Experiment Station, and approved for publication as Journal Series No. R-09313

\section{Materials and Methods}

Bedding plant seedlings (as 288 size plugs) were transplanted into $10-\mathrm{cm}$ pots $\left(610 \mathrm{~cm}^{3}\right)$ and were fertilized at each irrigation at a level of $150 \mathrm{mg} \cdot \mathrm{L}^{-1}$ of $\mathrm{N}$ from a $20 \mathrm{~N}-4.4 \mathrm{P}-16.6 \mathrm{~K}$ fertilizer. Irrigation was applied to the medium surface by hand. Except where indicated, the growing medium was Fafard II (Fafard, Anderson, S.C.). Temperatures ranged from a low of $18^{\circ} \mathrm{C}$ to a high of $29^{\circ} \mathrm{C}$. Unless otherwise indicated, all uniconazole sprays were applied at a volume of $200 \mathrm{~mL} \cdot \mathrm{m}^{-2}$.

'Double Madness Rose' petunia (Petunia $\times$ hybrida Vilm.), 'Showstopper Orange' impatiens (Impatiens wallerana Hook. f.), 'Wizard Rose' coleus (Solenostemon scutellarioides L.), and 'Cooler Rose' vinca [Catharanthus roseus (L.) G. Don.] were used to compare a preplant medium spray to a whole-plant spray applied 2 weeks after planting, which simulated a standard industry practice. For the medium spray treatments, the containers were filled with medium, the medium spray was applied and then the plugs were planted 1-2 $\mathrm{h}$ later. Treatments included uniconazole at three concentrations applied as a medium spray, a nontreated control, and a whole-plant spray. Uniconazole concentrations applied to the crops varied depending on the sensitivity of each, and the concentrations for the whole-plant sprays were 20, 20, 10, and $2 \mathrm{mg} \cdot \mathrm{L}^{-1}$, for petunia, coleus, impatiens, and vinca, respectively. The concentrations applied as a medium spray prior to planting were $1 \times$, $0.5 \times$, and $0.25 \times$ of the whole-plant spray. Plant height was measured 4 weeks after planting for petunia and at 5 weeks for the other crops. Plants were planted on 16Apr. 1998. Each crop was a separate experiment in a randomized complete-block design with three blocks and three plants per experimental unit. Data were analyzed by analysis of variance (ANOVA) and contrast comparison was used to compare means to the whole-plant spray treatment

The effect of pine bark as a medium component on the efficacy of uniconazole in a medium spray was evaluated using 'Pacifica' vinca and 'Dreams White' petunia. The experiments were $2 \times 4$ factorials with four blocks and two plants per experimental unit. The two media were Fafard II, which does not contain pine bark, and Metro Mix 300 (Scotts, Marysville, Ohio), which contains pine bark as previously described by Million et al. (1999b). Pine bark has been shown to be the primary medium component that affects plant growth regulator efficacy in medium drench applications (Million, 1998). The four uniconazole concentrations were $0,4,8$ and $16 \mathrm{mg} \cdot \mathrm{L}^{-1}$ for petunia and $0,0.5,1$, and $2 \mathrm{mg} \cdot \mathrm{L}^{-1}$ for vinca. Plants were planted on 18 Feb. 1999. Plant heights were measured 5 weeks after planting, and data were analyzed by ANOVA and regression analysis.

Spray volume effects in medium sprays were determined using 'Dreams White' petunia. Uniconazole at $1 \mathrm{mg} \cdot \mathrm{L}^{-1}$ was applied to the medium prior to planting using spray volumes of $0,100,200,300$, or $400 \mathrm{~mL} \cdot \mathrm{m}^{-2}$. There were three blocks and three plants per experimental unit. Plants were started on 18 Feb. 1999. Plant heights were determined 5 weeks after planting, and data were subjected to regression analysis.

\section{Results and Discussion}

Compared to the nontreated control plants, whole-plant uniconazole sprays produced shorter plants in all four crops, and the plants were of commercially acceptable quality. Heights of plants sprayed 2 weeks after planting were between $43 \%$ and $59 \%$ of the heights of nontreated plants (Figs. 1-4). It previously has been reported that uniconazole provides height control on these species (Barrett and Nell, 1992; Barrett and Erwin, 1994).

For impatiens, plants given the uniconazole medium spray at $10 \mathrm{mg} \cdot \mathrm{L}^{-1}$ were shorter than the plants receiving the whole-plant spray at $10 \mathrm{mg} \cdot \mathrm{L}^{-1}$ at 2 weeks (Fig. 1). The heights of plants given the medium spray at $2.5 \mathrm{mg} \cdot \mathrm{L}^{-1}$ were similar to heights of plants in the wholeplant spray treatment. Results for vinca (Fig. 2) were similar to those for impatiens. Compared to plants receiving $2 \mathrm{mg} \cdot \mathrm{L}^{-1}$ as a whole-plant spray, the plants given $0.5 \mathrm{mg} \cdot \mathrm{L}^{-1}$ as a medium spray had similar heights and plants in the 2$\mathrm{mg} \cdot \mathrm{L}^{-1}$ medium spray treatment were shorter. The results indicate that for impatiens and vinca uniconazole applied as a medium spray had greater efficacy than the whole-plant spray at 2 weeks after planting.

However, the difference between the medium spray and the whole-plant spray was not as great in petunia (Fig. 3) and coleus (Fig. 4). In these crops, the $20 \mathrm{mg} \cdot \mathrm{L}^{-1}$ of uniconazole applied prior to planting and at 2 weeks after planting produced plants with similar sizes, and the plants given $5 \mathrm{mg} \cdot \mathrm{L}^{-1}$ in a medium spray 


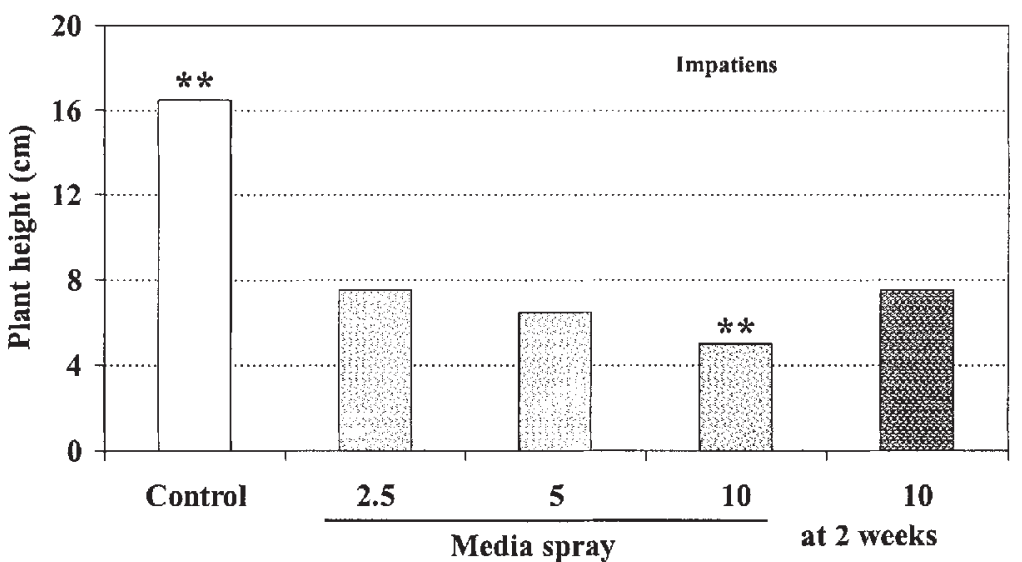

Uniconazole $\left(\mathrm{mg}^{\circ} \mathrm{L}^{-1}\right)$

Fig. 1. Uniconazole effects on height of 'Showstopper Orange' impatiens. Media sprays were applied to the medium in filled pots prior to planting. Application at 2 weeks was a whole-plant spray. The ** indicates means that are significantly different from the spray at 2 weeks treatment, determined by contrast comparison $(P<0.01)$.

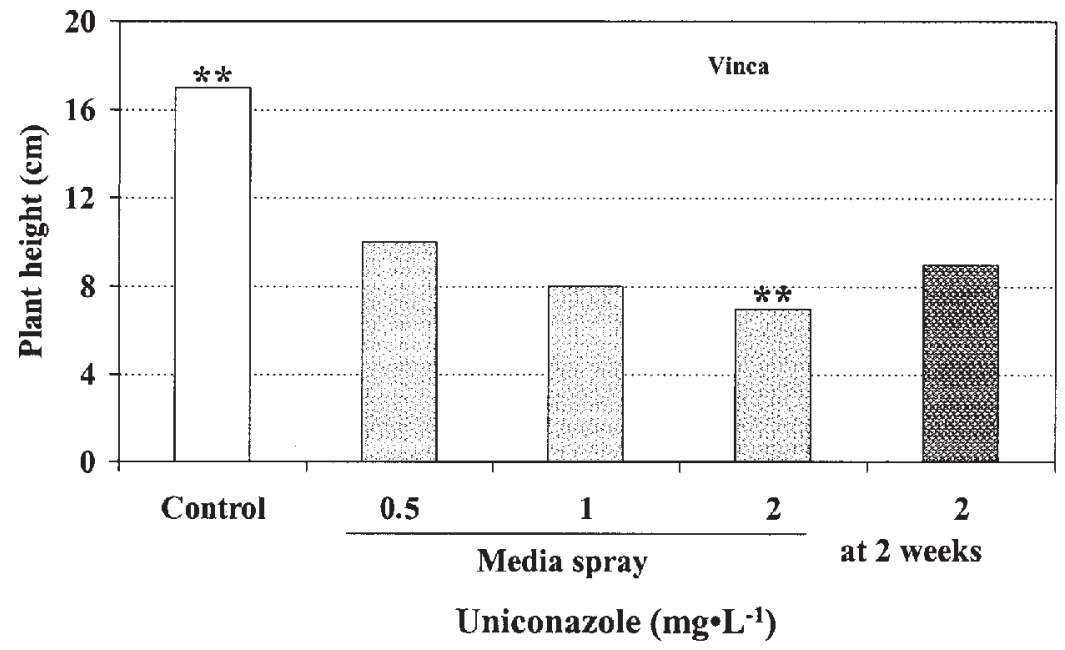

Fig. 2. Uniconazole effects on height of 'Cooler Rose' vinca. Media sprays were applied to the medium in filled pots prior to planting. Application at 2 weeks was a whole-plant spray. The ** indicates means that are significantly different from the spray at 2 weeks treatment, determined by contrast comparison $(P<0.01)$.

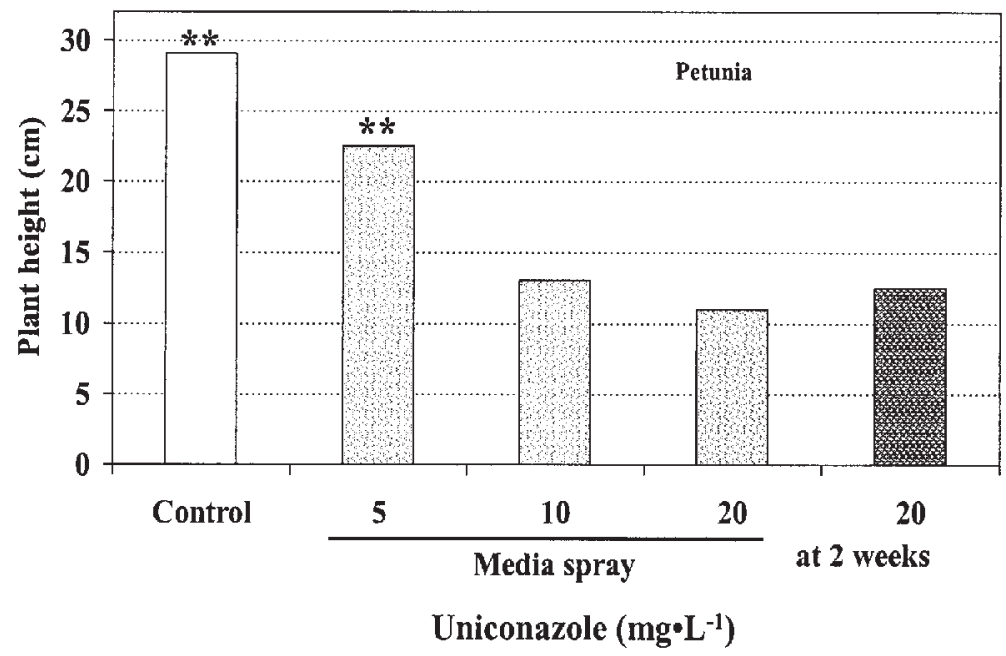

Fig. 3. Uniconazole effects on height of 'Double Madness Rose' petunia. Media sprays were applied to the medium in filled pots prior to planting. Application at 2 weeks was a whole-plant spray. The ** indicates means that are significantly different from the spray at 2 weeks treatment, determined by contrast comparison $(P<0.01)$. were taller than plants sprayed at 2 weeks with $20 \mathrm{mg} \cdot \mathrm{L}^{-1}$. Therefore, the results from these four crops indicate that the relative efficacy of medium sprays and whole-plant sprays may vary depending on species.

Higher concentrations of uniconazole in the medium sprays produced shorter plants than the lower concentrations for all four crops, as would generally be expected. This response is similar to the effect of increasing concentrations reported in previous studies of triazole growth regulators applied as a medium drench (Barrett and Nell, 1994), a whole-plant spray (Barrett and Nell, 1992), and in subirrigation water (Million et al., 1999a).

Million et al. (1999b) found that when paclobutrazol was applied as a drench to the medium surface, the paclobutrazol was initially located in the upper portions of the medium profile and moved down over time with subsequent irrigations. We speculate that the uniconazole sprayed to the medium surface in the present study moved down into the medium with irrigation and was taken up by the plant roots similar to a medium drench. We observed that the plants were taking up the uniconazole quickly, and by 1 week after planting, the effects of the uniconazole on stem elongation could be seen in plants growing in the sprayed medium.

It is well documented that pine bark as a component of container medium reduces the efficacy of uniconazole and other growth regulators applied as a medium drench (Million et al., 1998). In the current study, there was a significant interaction between medium and uniconazole concentration for both petunia (Fig. 5) and vinca(Fig. 6). As uniconazole concentration increased, plant height decreased for both the medium with and the one without pine bark. However, plants in the pine bark medium showed less response to increased concentration than those in the medium without bark. These results indicate that the efficacy of medium spray applications is affected by pine bark. The amount of chemical used in commercial applications will need to be adjusted based on the characteristics of the medium as the industry does with drench applications.

Spray volume has been shown to be an important source of variation in the efficacy of triazole growth regulators applied as a whole-plant spray (Barrett and Nell, 1990; Barrett et al., 1994). The petunias (Fig. 7) grown in medium sprayed with uniconazole at different spray volumes showed a negative linear relationship between plant height and spray volume. This indicates that in commercial situations applicators will need to insure medium sprays are applied uniformly as is the situation with a whole-plant spray application of triazole growth regulators.

While different spray volumes can be used for whole-plant sprays, $200 \mathrm{~mL} \cdot \mathrm{m}^{-2}$ has become the standard volume recommended on growth regulator labels and for making recommendations of concentrations for different crops (Barrett and Erwin, 1994). Likewise with medium spray applications, different spray volumes can be applied, but similar results can be obtained by adjusting 


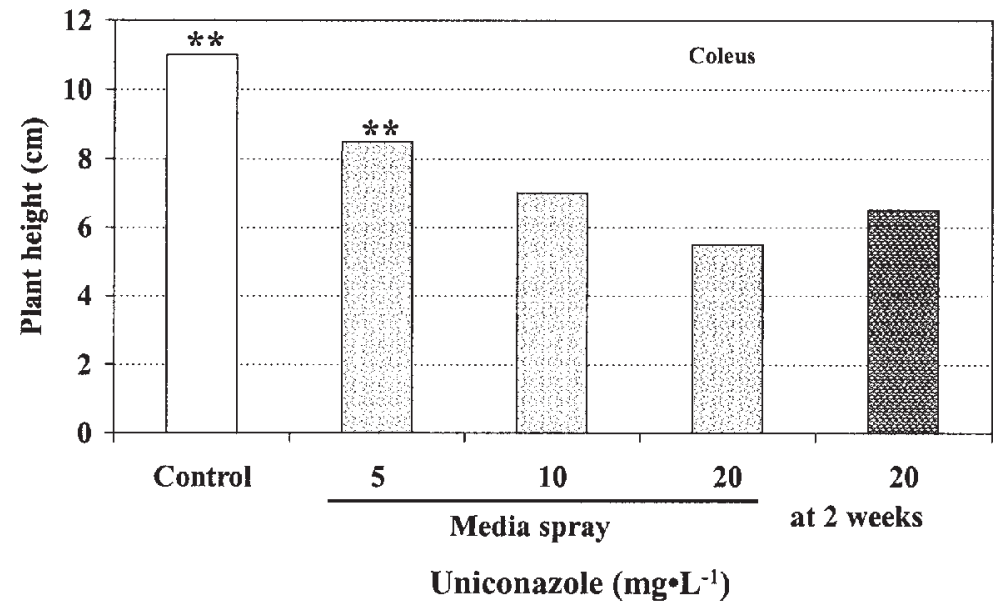

Fig. 4. Uniconazole effects on height of 'Wizard Rose' coleus. Media sprays were applied to the medium in filled pots prior to planting. Application at 2 weeks was a whole-plant spray. The ** indicates means that are significantly different from the spray at 2 weeks treatment, determined by contrast comparison $(P<0.01)$

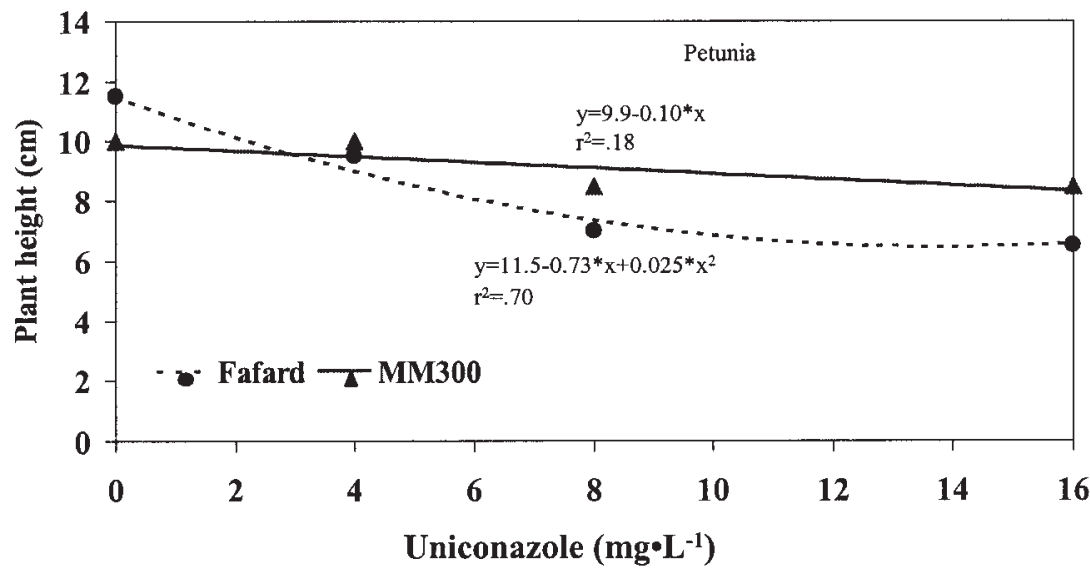

Fig. 5. The relationship between uniconazole concentration, medium and height for 'Dreams White' petunia. Metro Mix 300 contains pine bark, but Fafard II does not. Uniconazole was sprayed on surface of media prior to planting. Lines generated from data for individual plants $(n=32)$ and points are treatment means. Concentration $\times$ medium interaction was significant at $P<0.0001$.

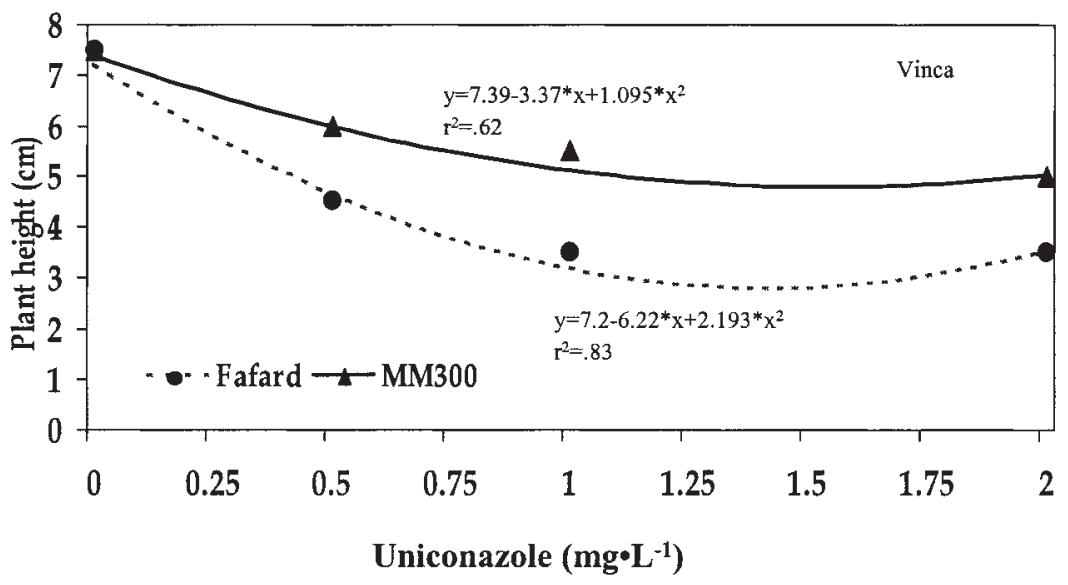

Fig. 6. The relationship between uniconazole concentration, medium and height for 'Pacifica' vinca petunia. Metro Mix 300 contains pine bark, but Fafard II does not. Uniconazole was sprayed on surface of media prior to planting. Lines generated from data for individual plants $(n=32)$, and points are treatment means. Concentration $\times$ medium interaction was significant at $P<0.001$. the concentration used. We propose that 200 $\mathrm{mL} \cdot \mathrm{m}^{-2}$ be adopted, also, as the standard spray volume for medium spray applications. This will allow easier comparisons of medium spray and whole-plant spray experimental results and commercial recommendations. Commercial applicators using heavier volumes for a medium spray can adjust the concentration for the differences in volume.

The species and cultivars of bedding plants used in this study vary considerably in their vigor and sensitivity to uniconazole. In commercial situations, petunia is one of the least sensitive bedding plants and vinca is considered among the most sensitive (Barrett and Erwin, 1994). The 'Double Madness Rose' petunia and 'Showstopper Orange' impatiens cultivars are more vigorous than most other commercial cultivars of those crops. However, the vigor of 'Wizard Rose' coleus, 'Cooler Rose'vinca and 'Dreams White' petunia is similar to most other commercial cultivars of those crops. The results from this study indicate that the medium spray technique for applying growth regulators has potential in commercial situations on a wide array of bedding plant crops.

Spray applications and medium drench applications of growth regulators are common industry practices, and when the terms "spray" or "drench" are used in chemical use recommendations the method of application is clear. The details provided in use recommendations for spraying a growth regulator to media will be different from either spray or drench recommendations. It will be important to keep the methods clearly differentiated. Thus, it has been suggested that the term "media spray" be used for situations where the chemical is sprayed to the medium surface either for sowing seeds or transplanting cuttings and seedlings (Barrett, 2000).

\section{Literature Cited}

Barrett, J.E. 2000. Applying chemical growth regulators, p 123-124. In: M.L. Gaston, S.A. Carver, L.A. Kunkle and M.F. Wilt (eds.). Tips on managing floriculture crop problems. Ohio Florists' Assn.. Columbus, Ohio.

Barrett, J.E. 2001. Mechanism of action, (In press). In: P. S. Konjoian and M.L. Gaston (eds.). Tips on the use of chemical growth regulators on floriculture crops. Ohio Florists' Assn. Columbus, Ohio.

Barrett, J.E. and T.A. Nell. 1990. Factors affecting efficacy of paclobutrazol and uniconazole on petunia and chrysanthemum. Acta Hort. 272: 229-234.

Barrett, J.E. and T.A. Nell. 1992. Efficacy of paclobutrazol and uniconazole on four bedding plant species. HortScience 27(8):896-897.

Barrett, J.E., C.A. Bartuska, and T.A. Nell. 1994. Efficacy of uniconazole on chrysanthemum altered by spray volume, timing, and site of application. HortScience 29:893-895.

Barrett, J.E. and T.A. Nell. 1994. Comparison of paclobutrazol drench and spike application for height control of potted floriculture crops. HortScience. 29(3):180-182.

Barrett, J.E. and J.E. Erwin. 1994. Bedding plant height control,p. 197-213. In: E. J. Holcomb (ed.). Bedding plants IV. Ball Publ., Batavia, Ill.

Davis, T.D., G.L. Steffans, and N. Sankhla. 1988. Triazole plant growth regulators, p. 63-105. In: J. Janick (ed.). Horticultural reviews. Vol. 10. Timber Press, Portland. 


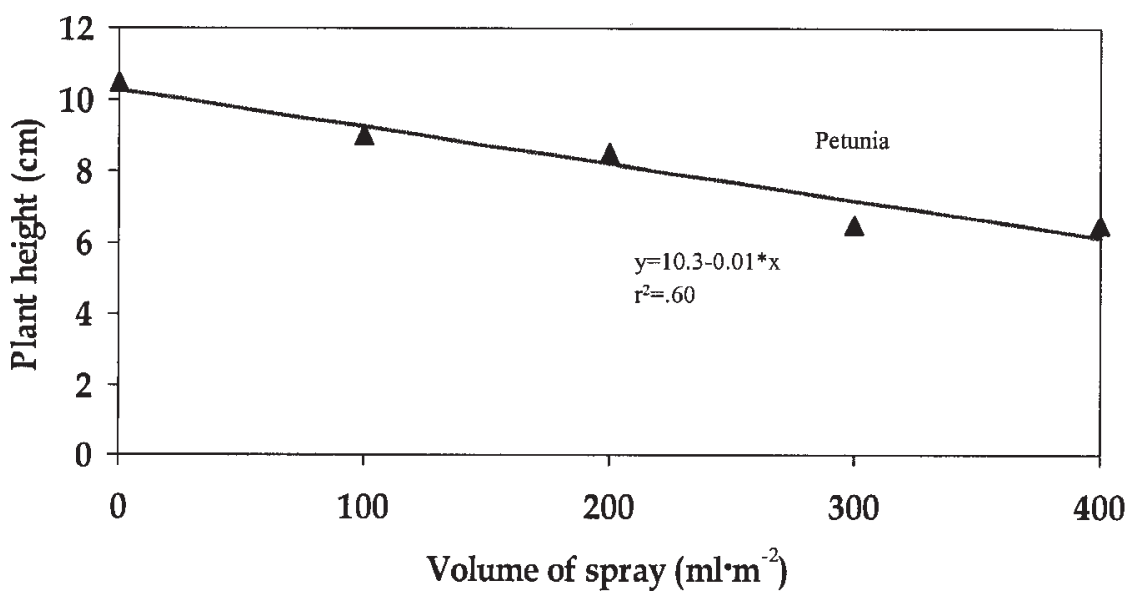

Fig. 7. The relationship between spray volume and height of 'Dreams White' petunia. Uniconazole at $1 \mathrm{mg} \cdot \mathrm{L}^{-1}$ was sprayed on media surface prior to planting. Lines generated from data for individual plants $(n=45)$, and points are treatment means.
Einert, A.E. 1976. Slow-release ancymidol for poinsettia by impregnation of clay pots. HortScience 11:374-375.

Million, J.B., J.E. Barrett, T.A. Nell and D.G. Clark. 1998. Influence of media components on efficacy of paclobutrazol in inhibiting growth of broccoli and petunia. HortScience 33:852-856.

Million, J.B., J.E. Barrett, T.A. Nell, and D.G. Clark. 1999a. Inhibiting growth of flowering crops with ancymidol and paclobutrazol in subirrigation water. HortScience 34:1103-1105.

Million, J.B., J.E. Barrett, T.A. Nell, and D.G. Clark. 1999b. Paclobutrazol distribution following Apalication to two media as determined by bioassay. HortScience 34:1099-1102.

Pasian, C.C. and M.A. Bennett. 2001. Placobutrazol soaked marigold, geranium, and tomato seeds produce short seedlings. HortScience 36:721-723.

Sanderson, K.C., W.C. Martin, Jr., and J. McGuire. 1988. Comparison of paclobutrazol tablets, drenches, gels, capsules, and sprays on chrysanthemum growth. HortScience 23:1008-1009.

Wulster, G.J. and T.M. Ombrello. 2000. Control of height and flowering of Ixia hybrids as container plants. HortScience 35:1087-1088. 